\title{
The importance of local settings: within-year variability in seawater temperature at South Bay, Western Antarctic Peninsula
}

\author{
César A Cárdenas ${ }^{\text {Corresp., }}{ }^{1}$ ， Marcelo González-Aravena ${ }^{1}$ ， Pamela A. Santibañez ${ }^{1}$ \\ ${ }^{1}$ Departamento Científico, Instituto Antártico Chileno, Punta Arenas, Chile \\ Corresponding Author: César A Cárdenas \\ Email address: ccardenas@inach.cl
}

The Western Antarctic Peninsula (WAP) has undergone significant changes in air and seawater temperatures during the last 50 years. Although highly stenotherm Antarctic organisms are expected to be severely affected by the increase of seawater temperature, high-resolution datasets of seawater temperature within coastal areas of the WAP (where diverse marine communities have been reported) are not commonly available. Here we report on within-year (2016-2017) variation in seawater temperature at three sites on Doumer Island, Palmer Archipelago, WAP. Within a year, Antarctic organisms in South Bay were exposed to water temperatures in excess of $2^{\circ} \mathrm{C}$ for more than 25 days and $2.5^{\circ} \mathrm{C}$ for more than 10 days. We recorded a temperature range between $-1.7^{\circ}$ to $3.0^{\circ} \mathrm{C}$. Warming of seawater temperature was 3.75 times faster after October 2016 than it was before October. Results from this study indicate that organisms at South Bay are already exposed to temperatures that are being used in experimental studies to evaluate physiological responses to thermal stress in WAP organisms. Continuous measurements of short to long-term variability in seawater temperature provides important information for parametrizing meaningful experimental treatments that aim to assess the local effects of environmental variation on Antarctic organisms under future climate scenarios. 
1

2 The importance of local settings: within-year variability in seawater temperature at South 3 Bay, Western Antarctic Peninsula

9 1Departamento Científico, Instituto Antártico Chileno (INACH), Plaza Muñoz Gamero 1055,

10 Punta Arenas 6200965, Chile

11

12 Corresponding Author:

13 César A. Cárdenas

14 Email address: ccardenas@inach.cl

15

16 


\section{Abstract}

18 The Western Antarctic Peninsula (WAP) has undergone significant changes in air and seawater

19 temperatures during the last 50 years. Although highly stenothermal Antarctic organisms are expected to be severely affected by the increase of seawater temperature, high-resolution datasets

21 of seawater temperature within coastal areas of the WAP (where diverse marine communities have been reported) are not commonly available. Here we report on within-year (2016-2017) variation in seawater temperature at three sites on Doumer Island, Palmer Archipelago, WAP. Within a year, Antarctic organisms in South Bay were exposed to water temperatures in excess of $2^{\circ} \mathrm{C}$ for more than 25 days and $2.5^{\circ} \mathrm{C}$ for more than 10 days. We recorded a temperature range between $-1.7^{\circ}$ to $3.0^{\circ} \mathrm{C}$. Warming of seawater temperature was 3.75 times faster after October 2016 than it was before October. Results from this study indicate that organisms at

South Bay are already exposed to temperatures that are being used in experimental studies to evaluate physiological responses to thermal stress in WAP organisms. Continuous measurements of short to long-term variability in seawater temperature provides important information for

31 parametrizing meaningful experimental treatments that aim to assess the local effects of 32 environmental variation on Antarctic organisms under future climate scenarios.

\section{Introduction}

35 Although there is an absence of continent-scale warming over Antarctica over the last 100 years

36 (Stenni et al., 2017), during the last 50 years the Western Antarctic Peninsula (WAP) has

37 undergone significant warming in air and seawater temperatures, with the later increasing by

$382^{\circ} \mathrm{C}$ (Cook et al., 2016; Meredith \& King, 2005; Stenni et al., 2017). Warming has contributed

39 to the range expansion of various marine flora (e.g., Convey \& Smith, 2006; Smith, 1994; Hill et

40 al., 2011), the loss of glacier mass, the retreat of ice shelves, and summer melting, with the latter 
41 being unprecedented over the past 1,000 years (Abram et al., 2013; Paolo, Fricker \& Padman, 42 2015). Increased snowfall on the Antarctic Peninsula has been linked to warming sea surface

43 temperatures in the western Pacific (Thomas et al., 2015, 2017) and the warming of WAP mid-

44 ocean depths (rather than the warming of air temperatures) has been proposed as the primary

45 driver of glacier retreat (e.g., Cook et al., 2016). These changes highlight the complexity of

46 environmental change occurring at the WAP and the need for high-resolution information on

47 regional- to local-scale patterns of climate change, to address its implications for marine polar

48 ecosystems (e.g., Clarke et al., 2007; Meredith, Stefels \& van Leeuwe, 2017).

49 Many Antarctic species are not well adapted to sudden temperature change because they

50 have evolved in one of the most stable environments on Earth (e.g., Peck, 2005; Morley et al.,

51 2016; Peck, Webb \& Bailey, 2014). Some Antarctic species are sensitive to even small changes

52 in temperature $\left(2-3^{\circ} \mathrm{C}\right.$ above the annual average $)$, losing the ability to perform essential

53 functions (Ingels et al., 2012; Peck, Morley \& Clark, 2010; Peck, Webb \& Bailey, 2004; Peck,

54 2005; Pörtner, Peck \& Somero, 2007). For example, the Antarctic scallop Adamussium colbecki

55 loses its ability to perform essential activities (Peck, 2005) with increases in seawater

56 temperature of $2-3{ }^{\circ} \mathrm{C}$, and attempts to acclimate individuals to temperatures above $2^{\circ} \mathrm{C}$ have

57 failed for this species (Bailey, Johnston \& Peck, 2005). Experiments using the Antarctic clam

58 Laternula elliptica, have shown that half of the individual died in 60 days at $3^{\circ} \mathrm{C}$, and for the

59 brittle star Ophionotus victoriae half of the individuals died in less than 30 days at $3^{\circ} \mathrm{C}$ (Turner et

60 al., 2009). In contrast others organisms, such as the sea urchin Sterechinus neumayeri, are

61 comparatively resistant to increases in seawater temperature (Ericson et al., 2012; Suckling et al.,

62 2015). Recent studies have highlighted the dramatic effects of warming waters on Antarctic

63 organisms at the community level (Ashton et al., 2017), where small increases in temperature $\left(1^{\circ}\right.$ 
64 C) altered community composition by reducing overall species diversity and evenness. The study

65 of resistance, adaptation and tolerance to environmental variation has become a key focus of

66 evaluating how Antarctic ecosystems respond to climate change (Gutt et al., 2012; Ingels et al.,

67 2012; Peck, 2005). Research to date has focused on identifying how Antarctic organisms respond

68 to the expected seawater temperature increase at community (Ashton et al., 2017), assemblage

69 (Peck et al., 2009) and species (physiological and molecular) levels (Cascella et al., 2015;

70 Ericson et al., 2012; Foo et al., 2016; González et al., 2016; Kapsenberg \& Hofmann, 2014; Peck

71 et al., 2009, 2014; Schram et al., 2015; Suckling et al., 2015), with the latter being the most

72 studied. To inform the design of studies that are relevant to future climate scenarios high-

73 resolution records of local to regional patterns of water temperature are required.

74 Due to the physical constraints that the Antarctic continent imposes on equipment and

75 sampling, obtaining long-term high-resolution water temperature data is often logistically

76 challenging. The urgent need to increase the spatio-temporal coverage of surface seawater

77 temperature data, with a focus on coastal areas, has been highlighted by several authors (Gutt et

78 al., 2017; Stenni et al., 2017). Although a number of moorings have been deployed along

79 channels and open waters in the WAP (See www.soos.aq/activities/soos-at-sea/moorings), there

80 remains a lack of long-term, high-resolution temperature data from shallow waters in coastal

81 zones dominated by diverse communities of sessile organisms with limited behavioral

82 thermoregulatory ability (Ashton et al., 2017). Fine-scale temporal (daily) data can be crucial for

83 inferring climatic impacts on survival, growth and reproduction (Kearney, Matzelle \& Helmuth,

84 2011), while monthly data is better suited to studying relationships between population dynamics

85 and climatic conditions (Gutt et al., 2017; Jan et al., 2017; Kennicutt et al., 2016). Observational

86 gaps in surface seawater temperature leave fractionated information that does not provide a 
87 coherent and robust picture of the current and future conditions occurring in Antarctic

88 ecosystems. In order to fill some of these gaps, high-resolution temporal observations are

89 required to advance ecosystem modelling and projections (Gutt et al., 2017).

90 Here we report for the first time extreme changes in shallow seawater temperature around

91 Doumer Island, Palmer Archipelago (WAP). We present shallow seawater temperatures recorded

92 over one year at high temporal resolution (hours), which can be used to parameterize future

93 physiological experiments.

\section{Material and Methods}

This study was conducted from the Chilean Yelcho Scientific Station in South Bay, Doumer

97 Island, Palmer Archipelago, WAP (Fig. 1), where diverse benthic communities have been

98 described (Cárdenas et al., 2016; Zamorano, 1983) (Fig. 2). Three HOBO pendant

99 temperature/light data loggers (Part \#UA-002-XX; Onset Computer Corp; accuracy: $\pm 0.5^{\circ} \mathrm{C}$ at

$1000^{\circ} \mathrm{C}$, resolution: $0.1^{\circ} \mathrm{C}$ at $0^{\circ} \mathrm{C}$ ) were deployed in January 2016 and recovered in February 2017

101 at three sites in South Bay (Fig. 1). Sites were separated by $\sim 1.5 \mathrm{~km}$ and are part of a research

102 project assessing the responses of Antarctic sponge assemblages to climate change. Data loggers

103 from two of the three sites (PY1; 6452'28.1'S; 63³4'36.0”W and PY4; 6451'58.6”S;

$\left.10463^{\circ} 37^{\prime} 46.7^{\prime \prime} \mathrm{W}\right)$ were at $10 \mathrm{~m}$ depth, whereas the third data logger (PY2; 6452’15.3”S;

$10563^{\circ} 33^{\prime} 52.2^{\prime \prime} \mathrm{W}$ ) was at a depth of $20 \mathrm{~m}$. Data was recorded every 2 hours at sites PY2 and PY4,

106 and every 1 hour at PY1. Sites PY1 and PY2 were located inside the bay and were characterized

107 by dense beds of Himantothallus grandifolius with a sub-canopy of crustose calcareous algae

108 and sponges on a boulder/gravel substrate (Fig. 2). PY4 was located at Cape Kemp, which is

109 regularly exposed to swell and is dominated by a mix of H. grandifolius, Desmarestia spp. and

110 Ascoseira mirabilis on a bedrock substrate. Benthic coverage of sponges at PY4 was higher than 
111 in sites inside the bay (Bravo, 2017). The data loggers at PY1, PY2 and PY4 recorded data for

112404,374 and 312 days, respectively. Data from PY4 stopped by late November (2016),

113 presumably after being damaged by an iceberg. The study was conducted under the permit

$114806 / 2015$ granted by the Chilean Antarctic Institute (INACH).

115 In order to describe non-linear, site-specific variability in the within-year patterns of

116 seawater temperature, we fit separate Generalized Additive Models (GAMs) to each of the three

117 sites, as they do not prescribe any particular form for the trend (Ferguson et al., 2008; Hastie \&

118 Tibshirani 1990; Orr et al., 2015). We chose GAMs instead of other techniques (e.g. linear

119 regression) because: (1) GAMs do not assume linearity and allow specification of the mean value

120 of the response and the systematic component using a link-function (Wood, 2006; Zuur, Ieno \&

121 Smith, 2007); (2) GAMs allow the application of an autoregressive structure to account for

122 dependency of serial correlations in time series data; and (3) GAMs allow the use of thin-plate

123 shrinkage smoothers to model temporal trends (recommended in Wood, 2006). The estimated

124 smooth trends are described by: (i) the shape of the estimated curve, (ii) a hypothesis test for no

125 variation over time, and (iii) $e d f$, which describes effect complexity and corresponds to the

126 amount of information used by each smoother. An $e d f$ of 0 indicates no variation, an $e d f$ of 1

127 indicates a linear relationship between the response and the covariate, and higher values

128 correspond to more complex non-linear relationships; and (4) GAMs allow the use of finite

129 differences (Curtis \& Simpson, 2014; Monteith et al., 2014) to estimate periods where the rate of

130 change (slope) is statistically different from zero (i.e., periods where the temperature is either

131 increasing or decreasing in a significant manner). This was achieved by computing the first

132 derivatives of the fitted trend. Uncertainty estimates were also calculated for the derivatives to

133 form approximate $95 \%$ confidence intervals. 
134 All models were fit using the R-programming language (version 3.3.3 by R Foundation

135 for Statistical Computing, 2017) and the package mgcv (Wood, 2004; Wood, 2006). The R code

136 and scripts are available in the supplemental material.

\section{7}

\section{Results}

139 All seawater temperature records showed significant seasonality (p-value $<0.01$; Fig. 3), with

140 clear minima in winter (July - September) and maxima in summer (January-March). Although

141 data loggers were located at different sites and depths (Fig. 1) they showed a similar seasonal

142 pattern throughout the year (Fig. 4), implying that the three sites are representative of broader

143 shallow waters temperatures in South Bay. In addition, sea surface temperatures within the same

144 time frame from Port Arthur (Palmer Station, 25 km from Yelcho Station) show similar

145 temperature ranges and patterns suggesting that the temperature variability reported could be

146 representative of the wider Palmer Archipelago. Mean daily temperatures ranged from $-1.7^{\circ}$ to

$1473.0^{\circ} \mathrm{C}\left(\right.$ range $\left.=4.7^{\circ} \mathrm{C}, \mathrm{SD}=1.1\right)$ at $\mathrm{PY} 1$ (the longest record, 404 days), from $-1.6^{\circ}$ to $1.00^{\circ} \mathrm{C}$

148 (range $=2.6^{\circ} \mathrm{C}, \mathrm{SD}=0.8$ ) at $\mathrm{PY} 4$ (the shortest record, 312 days), and from $-1.8^{\circ}$ to $1.8^{\circ} \mathrm{C}$

149 (range $\left.=3.6^{\circ} \mathrm{C}, \mathrm{SD}=0.8\right)$ at PY2. Seawater temperature differed between the $2016\left(\max 0.8^{\circ}\right.$

150 C) and $2017\left(\max 3.0^{\circ} \mathrm{C}\right)$ summers at PY1 (p-value $<0.01$; Figs. 5 and S1).

151 To identify periods of statistically significant change in the time series of seawater

152 temperature at PY1 we calculated the first derivative method from a second GAM model $(\mathrm{k}=58$,

$153 e d f=55.7$, p-value $<0.001$, Figs. 5 and S2), which allowed a closer examination of the

154 temperature variability at PY1 site. Figure 5 shows there were 26 periods of statistically

155 significant change throughout the year, 12 increases and 13 decreases. From all periods of

156 significant increasing temperatures, the rate of temperature increase $\left({ }^{\circ} \mathrm{C} \mathrm{day}{ }^{-1}\right)$ to which marine

157 organisms were subjected varied between 0.11 to $0.15^{\circ} \mathrm{C}_{\text {day }}^{-1}($ mean $0.13, \mathrm{SD}=0.01)$ after 
158 October 2016. In contrast, the rate of increase before October 2016 ranged between 0.04 and

$1590.07{ }^{\circ} \mathrm{C}$ day $^{-1}($ mean $=0.05, \mathrm{SD}=0.02 ;$ Table 1$)$.

\section{Discussion}

161 In recent years, several studies have focused on assessing how Antarctic organisms will adapt to

162 future environmental conditions (e.g., Cascella et al., 2015; Ericson et al., 2012; Peck, 2011,

163 2016; Peck et al., 2014; Schram et al., 2015). Existing studies have used different species,

164 methodologies and warming rates, which sometimes make comparing species-specific responses

165 and treatment effects difficult (Clark et al., 2017). In addition, most experimental studies have

166 used standard scenarios of climate change that are not necessarily relevant to nearshore areas that

167 may be affected by a higher degree of temperature variability than other marine environments

168 (e.g., Vargas et al., 2017). It is therefore important to incorporate realistic scenarios of

169 temperature change into evaluations of ecosystem responses to climate change across multiple

170 spatial and temporal scales (Gutt et al., 2017).

171 The present work provides the first yearlong record of shallow seawater temperatures

172 around Doumer Island and one of the few on the Palmer Archipelago, WAP. Results show short-

173 term variability and significant warming events. This constitutes important baseline information

174 that could be used to assess long-term trends in local seawater temperature, and inform future

175 physiological and molecular experimental studies in the area. Although HOBO data loggers have

176 an accuracy of $\pm 0.5^{\circ} \mathrm{C}$ at $0^{\circ} \mathrm{C}$ which could increase the temperature range reported in our

177 study, our results are in accordance with those obtained from 24-hour CTD measurements

178 carried out in parallel by other researchers during certain days of the field season. Results

179 demonstrate that marine organisms, at least in some coastal areas of Antarctica, are already

180 exposed seawater temperatures that have been widely used in physiological tolerance 
181 experiments to evaluate the effects of future climate scenarios. For example, observed

182 temperatures in this study of more than $2.0^{\circ} \mathrm{C}$ for more than 25 days or $2.5^{\circ} \mathrm{C}$ for more than ten

183 days within a year, have been used experimentally to test responses to acute heat stress (e.g. Peck

184 et al., 2009). Further, Waller et al. (2017) reported for the first time the presence of the bivalve

185 Laternula elliptica (has been used as a model to test the responses of Antarctic organisms to

186 warming sea temperatures) in intertidal habitats were sediment and air temperature reached more

187 than 7 to $10{ }^{\circ} \mathrm{C}$, respectively. That study (Waller et al., 2017) and the continuous records of

188 water temperature reported here suggest that we may need to rethink the temperature ranges used

189 in experimental setups to better reflect local conditions, as organisms occurring on different

190 regions of Antarctica might respond differently to environmental variation.

191 Short-term variability in water temperature is relatively low in Antarctic coastal

192 environments, with a mean annual temperature range of $\sim 3.1^{\circ} \mathrm{C}$ at some places such as Anvers

193 Island (Barnes et al., 2006); hence, it is expected to have very little impact on ecology (e.g.,

194 Clarke, 2001). However, recent work highlights the importance of environmental variability at

195 different scales, with acute thermal stress events and even timing of seasonal events being

196 suggested as critical factors driving physiological, ecological and evolutionary processes (See

197 Fordham et al., 2017 and references therein). Although our time-series of continuous, directly-

198 measured sea temperatures is limited to a year, it shows the complete annual pattern and

199 existence of dynamic variations within South Bay, Doumer Island. Our results are in accordance

200 with sea surface temperature data from Port Arthur, Palmer Station in Anvers Island

201 (http://pal.lternet.edu), which is approximately $25 \mathrm{~km}$ west of Doumer Island, suggesting this

202 pattern occurs at least throughout the Palmer Archipelago (Fig. 4). Additionally, there are some 
203 long-term data sets at WAP for a few areas (e.g. Palmer LTER, Rothera Station-BAS Database)

204 that allowed comparison.

205 Our results show that marine organisms at South Bay were exposed to a broad annual

206 temperature range from $-1.7^{\circ}$ to $3.0^{\circ} \mathrm{C}$ with a range of $4.7^{\circ} \mathrm{C}$. Antarctic marine organisms are

207 recognized as the most stenothermal on Earth (i.e., organisms only capable of surviving over a

208 narrow range of temperature). For example, some species such as the brittlestar Ophionotus

209 victoriae cannot tolerate acclimation temperatures of more than $2-3^{\circ} \mathrm{C}$ (Peck et al., 2009).

210 Based on an experimental approach using $3.5^{\circ} \mathrm{C}$ seawater temperatures (representative of

211 current summer transient peaks of sea surface recorded at Port Arthur, Anvers Island), Schram et

212 al. (2015) suggested that an increase in the frequency and peaks of warning events may affect

213 feeding preferences of amphipod species. Considering the observed within-year trends in water

214 temperature recorded at South Bay, it is important to assess and monitor the potential effects on

215 physiological and ecological processes due to rising water temperatures. The effects of increased

216 seawater in sessile organisms, such as sponges, which form diverse assemblages in the shallows

217 (Cárdenas et al., 2016), have not been well studied in Antarctica. Evidence from other latitudes

218 suggests some sponge species might be highly vulnerable to small increases in seawater

219 temperature (Lopez-Legentil et al., 2011), however this remains to be tested in Antarctic species.

220 Previous work has shown that even small variations in environmental condition can have

221 significant effects on the physiology of some organisms (Morley et al. 2010). This is highly

222 relevant considering thermal limits cannot only vary spatially but also between years and even

223 seasons (Morley et al., 2012, 2016). Laboratory studies have used rapid warming rates, which are

$224100-10,000$ times faster than those observed here and predicted for seawater temperatures (Peck

225 et al., 2009). Our HOBO data loggers recorded a significant change in the warming rates before 
226 and after October 2016 (3.75 times higher after October 2016, Table 1, Fig. 4). Warming rates

227 are positively correlated with Critical Thermal Maximum (CTMax), which is used to describe

228 the effects of heat tolerance on different organisms (Bilyk \& DeVries, 2011; Cascella et al.,

229 2015; Mora \& Maya, 2006; Peck et al., 2009; Peck et al., 2014; Terblanche et al., 2007). Lower

230 CTMax results from slower warming rates and consequently poorer thermal tolerance. Our

231 results suggest that caution must be applied when interpreting CTMax derived from laboratory

232 experiments because some of those values were obtained by using warming rates that are far

233 faster than that experienced by organisms in their natural habitats (in this study between 0.03 and

$2340.15^{\circ} \mathrm{C}$ per day). In addition, differences in warming rates before and after October $2016(0.05$

235 [SD: 0.01] vs. 0.13 [SD: 0.02$]^{\circ} \mathrm{C}$ day) can have a significant impact on the mechanisms

236 dictating the survival limits of benthic organisms (see Peck et al., 2009).

Recent studies have shown the importance of including natural local variability (with

several treatment levels) in experimental designs to avoid exposing organisms to unrealistic

239 scenarios (Vargas et al., 2017). Local conditions should be taken into account since organisms occurring in areas where high variability occurs, might show different responses to stressors

241 compared to those from areas where environmental variability is lower. For instance, it is

242 possible that organisms inhabiting zones that have more stable temperatures (e.g., East

243 Antarctica) might show different responses to warming than those inhabiting areas exposed to

244 higher temperature variability such as the WAP. The use of continuous measurements of

245 temperature and other environmental data constitute a valuable tool to identify long- and short-

246 term variability in coastal waters. This type of information can provide more realistic scenarios

247 based on local conditions in future studies assessing the effect of environmental variation on

248 Antarctic organisms. 


\section{Conclusions}

251 The use of continuous measurements of environmental data such as seawater temperature, can

252 provide key information to identify current patterns of long- and short-term variability in

253 Antarctic coastal waters. Such information is important in informing realistic scenarios for

254 experimental work assessing the local effect of environmental variation on Antarctic organisms.

255 Our results show that benthic organisms at South Bay were exposed to high local variability in

256 seawater temperature (range: $-1.7^{\circ}$ to $3.0^{\circ}$ ), rates of warming $\left(0.04\right.$ to $0.15^{\circ} \mathrm{C}$ day $^{-1}$ ), and

257 duration of elevated temperatures (more than 25 days over $2{ }^{\circ} \mathrm{C}$ ). These results demonstrate that

258 seawater temperatures at depths of 10 to $20 \mathrm{~m}$ during summer in South Bay already reach those

259 predicted temperatures for 2100. Although our data was collected in a relatively short period (1

260 year), due to scarcity of sea temperature data at WAP environments, especially in coastal areas, it

261 represents an important source of baseline information, that along with future high-resolution

262 temporal observations on local temperature, will help us to better understand and forecast climate

263 impacts on Antarctic marine organisms and ecosystems.

\section{Acknowledgements}

265 The authors would like to thank F. Beaujot, L. Novoa, D. Bravo, K. Attard. L. Rovelli, E.

266 DaForno, F. Ressia and the INACH personnel at Yelcho Antarctic Research Station for help

267 during field activities. We also thank Shane W. Geange for his assistance leading to an improved

268 version of the manuscript. This paper contributes to the SCAR AnT-ERA programme.

\section{References}

271

272

Abram, NJ, Mulvaney, R, Wolff, EW, Triest, J, Kipfstuhl, S, Trusel, LD, Vimeux F, Fleet L, Arrowsmith, C. 2013. Acceleration of snow melt in an Antarctic Peninsula ice core

273 during the twentieth century. Nature Geoscience, 6: 404-411. 
274

275

276

277

278

279

280

281

282

283

284

285

286

287

288

289

290

291

292

293

294

295

296

297

298

299

300

301

302

303

304

305

306

307

308

309

310

311

312

313

314

315

316

317

Ashton GV, Morley SA, Barnes DKA, Clark MS, Peck LS. 2017. Warming by $1^{\circ} \mathrm{C}$ drives species and assemblage level responses in Antarctica's marine shallows. Current Biology 27:1-8.

Bailey DM, Johnston IA, Peck LS. 2005. Invertebrate muscle performance at high latitude: swimming activity in the Antarctic scallop, Adamussium colbecki. Polar Biology, 28: 464-469.

Barnes DKA, Fuentes V, Clarke A, Schloss IR, Wallace MI. 2006. Spatial temporal variation in shallow seawater temperatures around Antarctica. Deep Sea Research II 53:853-865.

Bravo D. 2017. Análisis de patrones de biodiversidad, distribución espacial y abundancia del ensamble de esponjas en Isla Doumer (Archipiélago de Palmer: Península Antártica) Licenciado en Biología Marina. Universidad de Valparaíso, Chile.

Bilyk KT, DeVries AL. 2011. Heat tolerance and its plasticity in Antarctic fishes. Comparative Biochemistry and Physiology Part A: Molecular \& Integrative Physiology 158.

Cárdenas CA, Newcombe EM, Hajdu E, González-Aravena M, Geange SW, Bell JJ. 2016. Sponge richness on algae-dominated rocky reefs in the Western Antarctic Peninsula and the Magellan Strait. Polar Research 35:30532.

Cascella K, Jollivet D, Papot C, Léger N, Corre E, Ravaux J, Clark MS, Toullec J-Y. 2015. Diversification, evolution and sub-functionalization of $70 \mathrm{kDa}$ heat-shock proteins in two sister species of Antarctic Krill: differences in thermal habitats, responses and implications under climate change. PloS One 10:e121642.

Clark MS, Peck LS. 2009. HSP70 heat shock proteins and environmental stress in Antarctic marine organisms: A mini-review. Marine Genomics 2:11-18.

Clark MS, Sommer U, Sihra JK, Thorne MAS, Morley SA, King M, Viant MR, Peck LS. 2017. Biodiversity in marine invertebrate responses to acute warming revealed by a comparative multi-omics approach. Global Change Biology 23: 318-330.

Clarke A. 2001. Benthic organisms and environmental variability in Antarctica: responses to seasonal, decadal and long-term change. Ocean and Polar Research 23:433-440.

Clarke A, Murphy EJ, Meredith MP, King JC, Peck LS, Barnes DKA, Smith RC. 2007. Climate change and the marine ecosystem of the western Antarctic Peninsula. Philosophical Transactions of the Royal Society of London B Biological Sciences 362:149-166. $10.1098 /$ rstb.2006.1958

Convey P, Smith RIL. 2006. Responses of Antarctic ecosystems to climate change. Plant Ecology 182:1-10

Cook AJ, Holland PR, Meredith MP, Murray T, Luckman A, Vaughan DG. 2016. Ocean forcing of glacier retreat in the western Antarctic Peninsula. Science 353:283-286.

Curtis CJ, Simpson GL. 2014. Trends in bulk deposition of acidity in the UK, 1988-2007, assessed using additive models. Ecological Indicators 37:274-286.

Ericson JA, Ho MA, Miskelly A, King CK, Virtue P, Tilbrook B, Byrne M. 2012. Combined effects of two ocean change stressors, warming and acidification, on fertilization and early development of the Antarctic echinoid Sterechinus neumayeri. Polar Biology 35:1027-1034.

Ferguson CA, Carvalho L, Scott EM, Bowman AW, Kirika A. 2008. Assessing ecological responses to environmental change using statistical models. Journal of Applied Ecology 45:193-203. 
318 Fordham DA, Saltré F, Brown SC, Mellin C, Wigley TML. 2017. Why decadal to century

319

320

321

322

323

324

325

326

327

328

329

330

331

332

333

334

335

336

337

338

339

340

341

342

343

344

345

346

347

348

349

350

351

352

353

354

355

356

357

358

359

360

361

362

363 timescale paleoclimate data are needed to explain present-day patterns of biological diversity and change. Global Change Biology (Online version):1-11.

Foo SA, Sparks KM, Uthicke S, Karelitz K, Barker B, Byrne M, Lamare M. 2016. Contributions of genetic and environmental variance in early development of the Antarctic sea urchin Sterechinus neumayeri in response to increased ocean temperature and acidification. Marine Biology 163:130.

González K, Gaitán-Espitia J, Font A, Cárdenas CA, González-Aravena M. 2016. Expression pattern of heat shock proteins during acute thermal stress in the Antarctic sea urchin, Sterechinus neumayeri. Revista Chilena de Historia Natural 89:2. 10.1186/s40693-0160052-z

Gutt J, Isla E, Bertler AN, Bodeker GE, Bracegirdle TJ, Cavanagh RD, Comiso JC, Convey P, Cummings V, De Conto R, De Master D, di Prisco G, d'Ovidio F, Griffiths HJ, Khan AL, López-Martínez J, Murray AE, Nielsen UN, Ott S, Post A, Ropert-Coudert Y, Saucède T, Scherer R, Schiaparelli S, Schloss IR, Smith CR, Stefels J, Stevens C, Strugnell JM, Trimborn S, Verde C, Verleyen E, Wall DH, Wilson NG, Xavier JC. 2017. Crossdisciplinarity in the advance of Antarctic ecosystem research. Marine Genomics (In press).

Gutt J, Adams B, Bracegirdle T, Cowan D, Cummings V, di Prisco G, Gradinger R, Isla E, McIntyre T, Murphy E, Peck L, Schloss I, Smith C, Suckling C, Takahashi A, Verde C, Wall D, Xavier J. 2012. Antarctic Thresholds - Ecosystem Resilience and Adaptation: a new SCAR-Biology Programme. Polarforschung 82:147-150.

Hastie TJ, Tibshirani RJ. 1990. Generalized additive models. New York: Chapman \& Hall. Hill PW, Farrar J, Roberts P, Farrell M, Grant H, Newsham KK, Hopkins DW, Bardgett R, Jones DL. 2011. Vascular plant success in a warming Antarctic may be due to efficient nitrogen acquisition. Nature Climate Change 1:50-53.

Ingels J, Vanreusel A, Brandt A, Catarino AI, David B, De Ridder C, Dubois P, Gooday AJ, Martin P, Pasotti F, Robert H. 2012. Possible effects of global environmental changes on Antarctic benthos: a synthesis across five major taxa. Ecology and Evolution 2:453-485.

Jan PL, Farcy O, Boireau J, Le Texier E, Baudoin A, Le Gouar P, Puechnaille SJ, Petit EJ. 2017. Which temporal resolution to consider when investigating the impact of climatic data on population dynamics? The case of the lesser horseshoe bat (Rhinolophus hipposideros). Oecologia 184: 749-761.

Kapsenberg L, Hofmann GE. 2014. Signals of resilience to ocean change: high thermal tolerance of early stage Antarctic sea urchins (Sterechinus neumayeri) reared under present-day and future pCO2 and temperature. Polar Biology:967-980.

Kearney MR, Matzelle A, Helmuth B. 2012. Biomechanics meets the ecological niche: the importance of temporal data resolution. Journal of Experimental Biology 215: 922-933.

Kennicutt MC, Kim YD, Finnemore-Rogan M, Anandakrishnan S, Chown SL, Colwell S, Cowan D, Escutia C, Frenot Y, Hall J, Liggett D, McDonald A, Nixdorf U, Siegert MJ, Storey J, Wåhlin A, Weathewax A, Wilson GA, Wilson T, Wooding R, Ackley S, Biebow N, Blankenship D, Bo S, Baesemann J, Cárdenas CA, Cassano J, Danhong C, Dañobeitia JJ, Francis J, Guldahl J, Hashida G, Jimenz Corbalan L, Klepikov A, Lee J, Leppe M, Lijun F, López-Martinez J, Memolli M, Motoyoshi Y, Mousalle Bueno R, Negrete J, Ojeda Cárdenes MA, Proaño Silva M, Ramos-Garcia S, Sala H, Sheppard P, Shin H, Shijie X, Shiraishi K, Stockings T, Trotter S, Vaughan DG, Viera Da Unha De 
364

365

366

367

368

369

370

371

372

373

374

375

376

377

378

379

380

381

382

383

384

385

386

387

388

389

390

391

392

393

394

395

396

397

398

399

400

401

402

403

404

405

406

407

408

409

Menezes J, Vlasich V, Weijia Q, Winthers J-G, Miller H, Rintoul S, Yang H. 2016. Delivering 21st century Antarctic and Southern Ocean science. Antarctic Science 28: 407-423.

Lautenbach S, Seppelt R, Liebscher J, Dormann CF. 2012. Spatial and temporal trends of global pollination benefit. PloS One 7:e35954.

Lopez-Legentil S, Song B, McMurray SE, Pawlik JR. 2011. Bleaching and stress in coral reef ecosystems: hsp70 expression by the giant barrel sponge Xestospongia muta. Molecular Ecology 17:1840-1849.

Meredith MP, King JC. 2005. Rapid climate change in the ocean west of the Antarctic Peninsula during the second half of the 20th century. Geophysical Research Letters 32:L19604L19609.

Meredith MP, Stefels J, van Leeuwe M. 2017. Marine studies at the western Antarctic Peninsula: Priorities, progress and prognosis. Deep Sea Research Part II: Tropical Studies in Oceanography 139:1-8.

Monteith DT, Evans CD, Henrys PA, Simpson GL, Malcolm IA. 2014. Trends in the hydrochemistry of acid-sensitive surface waters in the UK 1988-2008. Ecological Indicators 37:287-303.

Mora C, Maya MF. 2006. Effect of the rate of temperature increase of the dynamic method on the heat tolerance of fishes. Journal of Thermal Biology 31:337-341.

Morley SA, Griffiths HJ, Barnes DKA, Peck LS. 2010. South Georgia: a key location for linking physiological capacity to distributional changes in response to climate change. Antarctic Science 22:774-781.

Morley SA, Martin SM, Bates AE, Clark MS, Ericson J, Lamare M, Peck LS. 2012. Spatial and temporal variation in the heat tolerance limits of two abundant Southern Ocean invertebrates. Marine Ecology Progress Series 450:81-92.

Morley SA, Bates AE, Lamare M, Richard J, Nguyen KD, Brown J, Peck LS. 2016. Rates of warming and the global sensitivity of shallow water marine invertebrates to elevated temperature. Journal of the Marine Biological Association of the United Kingdom 96:159-165.

Orr HG, Simpson GL, des Clers S, Watts G, Hughes M, Hannaford J, M.J. D, Laizé CLR, Wilby RL, Battarbee RW, Evans R. 2015. Detecting changing river temperatures in England and Wales. Hydrological Processes 29:752-766.

Paolo FS, Fricker HA, Padman L. 2015. Volume loss from Antarctic ice shelves is accelerating. Science, 348(6232), 327-331.

Peck L, Morley S, Clark M. 2010. Poor acclimation capacities in Antarctic marine ectotherms. Marine Biology 157:2051-2059.

Peck LS, Webb K, Bailey, D. 2004. Extreme sensitivity of biological function to temperature in Antarctic marine species. Functional Ecology 18: 625-630.

Peck LS. 2005. Prospects for survival in the Southern Ocean: vulnerability of benthic species to temperature change. Antarctic Science 17:497-507.

Peck LS. 2011. Organisms and responses to environmental change. Marine Genomics 4:237243.

Peck LS. 2016. A cold limit to adaptation in the sea. Trends in Ecology and Evolution 31:13-26.

Peck LS, Clark MS, Morley SA, Massey A, Rossett H. 2009. Animal temperature limits and ecological relevance: effects of size, activity and rates of change. Functional Ecology 23:248-256. 
410 Peck LS, Morley SA, Richard J, Clark MS. 2014. Acclimation and thermal tolerance in Antarctic

411

412

413

414

415

416

417

418

419

420

421

422

423

424

425

426

427

428

429

430

431

432

433

434

435

436

437

438

439

440

441

442

443

444

445

446

447

448

449

450

451

452

453

454

455 marine ectotherms. The Journal of Experimental Biology 217:16-22.

Pörtner HO, Peck L, Somero G. 2007. Thermal limits and adaptation in marine Antarctic ectotherms: an integrative view. Philosophical Transactions of the Royal Society of London B Biological Sciences 362:2233-2258.

Schram JB, McClintock JB, Amsler CD, Baker BJ. 2015. Impacts of acute elevater seawater temperature on the feeding preferences of an Antarctic amphipod toward chemically deterred macroalgae. Marine Biology 162:425-433.

Smith RL. 1994. Vascular plants as bioindicators of regional warming in Antarctica. Oecologia, 99(3): 322-328.

Stenni B, Curran MAJ, Abram NJ, Orsi A, Goursaud S, Masson-Delmotte V, Neukom R, Goosse H, Divine D, van Ommen T, Steig EJ, Dixon DA, Thomas ER, Bertler NAN, Isaksson E, Ekaykin A, Werner M, Frezzotti M. 2017. Antarctic climate variability on regional and continental scales over the last 2000 years. Climate of the Past 13:1609-1634.

Suckling CC, Clark MS, Richard JS, Morley SA, Thorne MS, Harper EM, Peck LS. 2015. Adult acclimation to combined temperature and $\mathrm{pH}$ stressors significantly enhances reproductive outcomes compared to short-term exposures. Journal of Animal Ecology 84:773-784.

Terblanche JS, Deere JA, Clusella-Trullas S, Janion C, Chown SL. 2007. Critical thermal limits depend on methodological context. Proceedings of the Royal Society B: Biological Sciences 1628:2935-2943.

Thomas ER, Hosking JS, Tuckwell RR, Warren RA, Ludlow EC. 2015. Twentieth century increase in snowfall in coastal West Antarctica. Geophysical Research Letters 42:93879393.

Thomas ER, van Wessem JM, Roberts J, Isaksson E, Schlosser E, Fudge TJ, Vallelonga P, Medley B, Lenaerts J, Bertler N, van den Broeke MR, Dixon DA, Frezzotti M, Stenni B, Curran M, Ekaykin AA. 2017. Regional Antarctic snow accumulation over the past 1000 years. Climate of the Past 13: 1491-1513.

Turner, J, Bindschadler, R, Convey, P, Di Prisco, G, Fahrbach, E, Gutt, J, Hodgson DA, Mayewski PA, Summerhayes, C. 2009. Antarctic climate change and the environment. Cambridge, Scientific Committee on Antarctic Research.

Vargas CA, Lagos NA, Lardies MA, Duarte C, Manriquez PH, Aguilera VM, Broitman B, Widdicombe S, Dupont S. 2017. Species specific responses to ocean acidification should account for local adaptation and adaptative plasticity. Nature Ecology \& Evolution 1:0084.

Waller CL, Overall A, Fitzcharles EM, Griffiths H. 2017. First report of Laternula elliptica in the Antarctic intertidal zone. Polar Biology 40:227-230.

Wood SN. 2004. Stable and efficient multiple smoothing parameter estimation for generalized additive models. Journal of the American Statistical Association 99:673-686.

Wood SN. 2006. Generalized Additive Models: an introduction with R: Chapman \& Hall/CRC.

Zamorano JH. 1983. Zonación y biomasa de la macrofauna bentónica en Bahía South, Archipiélago de Palmer, Antártica. INACH Serie Cientifica 30:27-38.

Zuur AF, Ieno EN, Smith GM. 2007. Analysing Ecological Data, 1st ed. Springer Science+Bussines Media, LLC, New York, USA. 
Figure 1

Study site

Locations of HOBO temperature/light data loggers deployments for studying sponge assemblages at Doumer Island (Palmer, Archipelago), WAP.

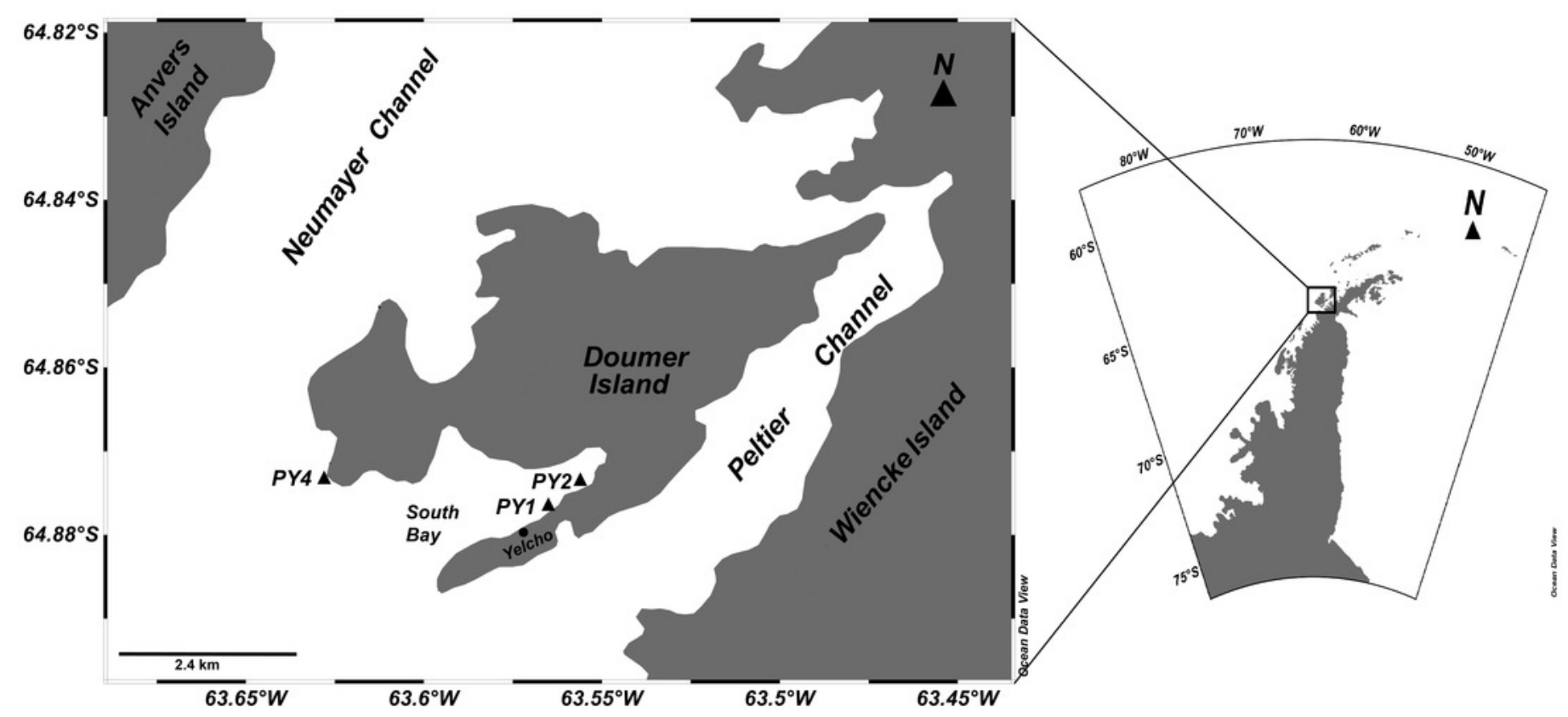


Figure 2

Benthic communities at Doumer Island (Palmer Archipelago), WAP

A) algae-dominated zones (10 $\mathrm{m}$ depth), where $\mathrm{B}$ ) diverse sponge assemblages have been identified underneath the algal canopy. The area showed in B is approximately $80 \mathrm{~cm} \times 50$ $\mathrm{cm}$. 


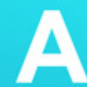

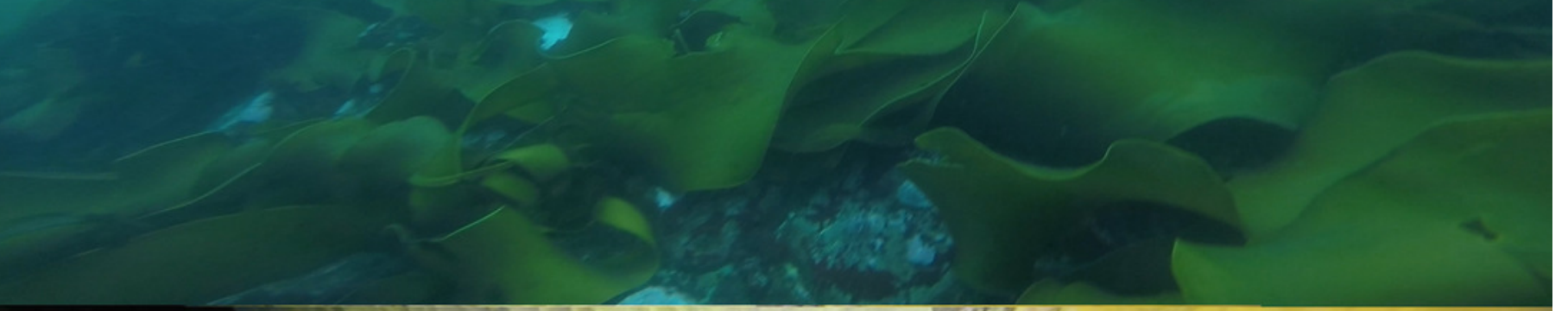

\section{B}
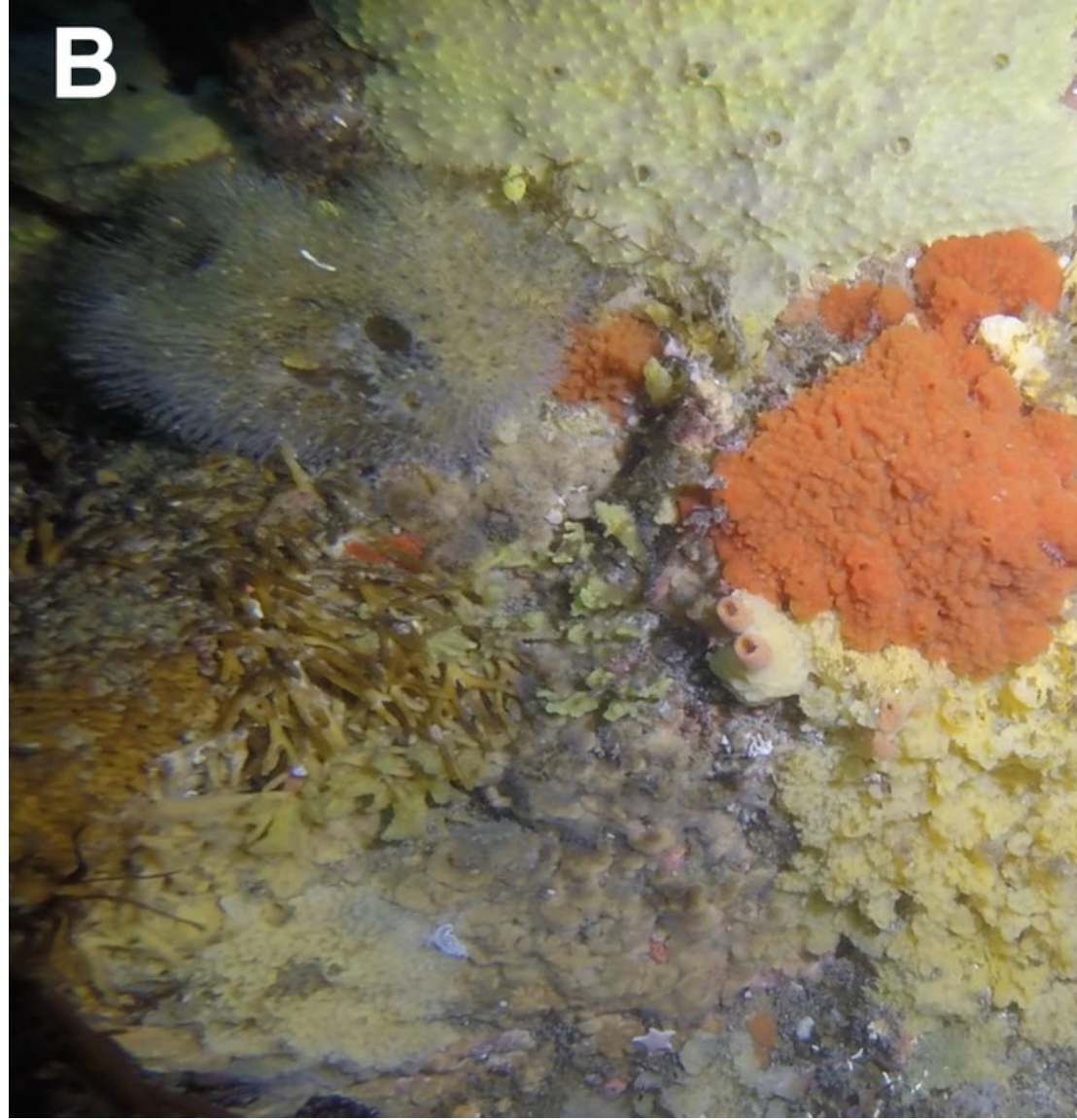
Figure 3

Daily mean seawater temperature

Within-year GAM (solid line) of daily mean seawater temperature $\left({ }^{\circ} \mathrm{C}\right)$ in $(\mathrm{A})$ PY1-10m (edf $=$ 6.7, $\mathrm{p}$-value $<0.001,404$ days), (B) PY4-10 $\mathrm{m}$ (edf $=5.7, \mathrm{P}<0.001,312$ days) and (C) PY2-20 $\mathrm{m}(\mathrm{edf}=7.1, \mathrm{P}<0.001,374$ days), respectively, at South Bay, Doumer Island, WAP. Black solid curves are the fitted seasonal model from the GAM. Colored areas correspond to 95\% confidence bands and the colored thin lines are the observational data (temperature daily means).

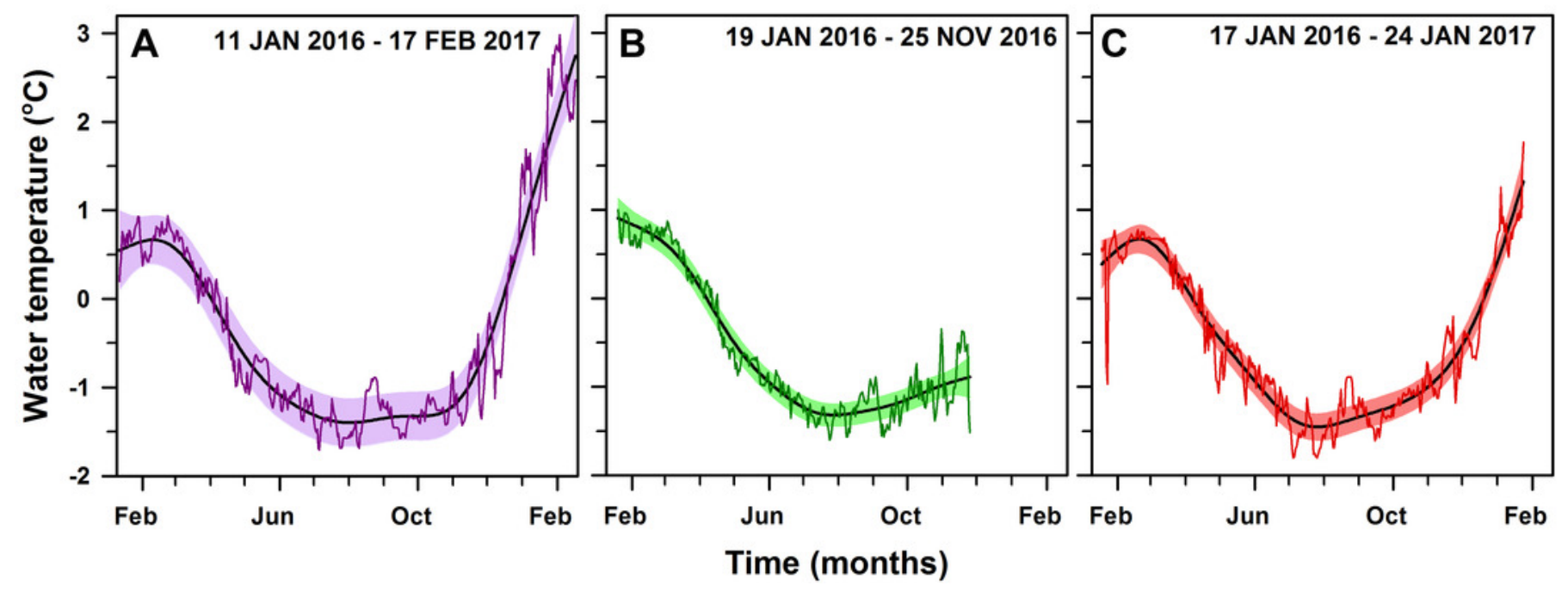


Figure 4

Shallow sea water temperatures recorded at Doumer Island

Full records of shallow sea water temperatures recorded every 2 hours at PY2- $20 \mathrm{~m}$ (red dots) and PY4-10 m (green dots), and every 1 hour at PY1-10 m (violet dots). Grey diamonds represent sea surface temperature average for the day, taken from Port Arthur (Palmer Station) in Anvers Island (http://pal.Iternet.edu).

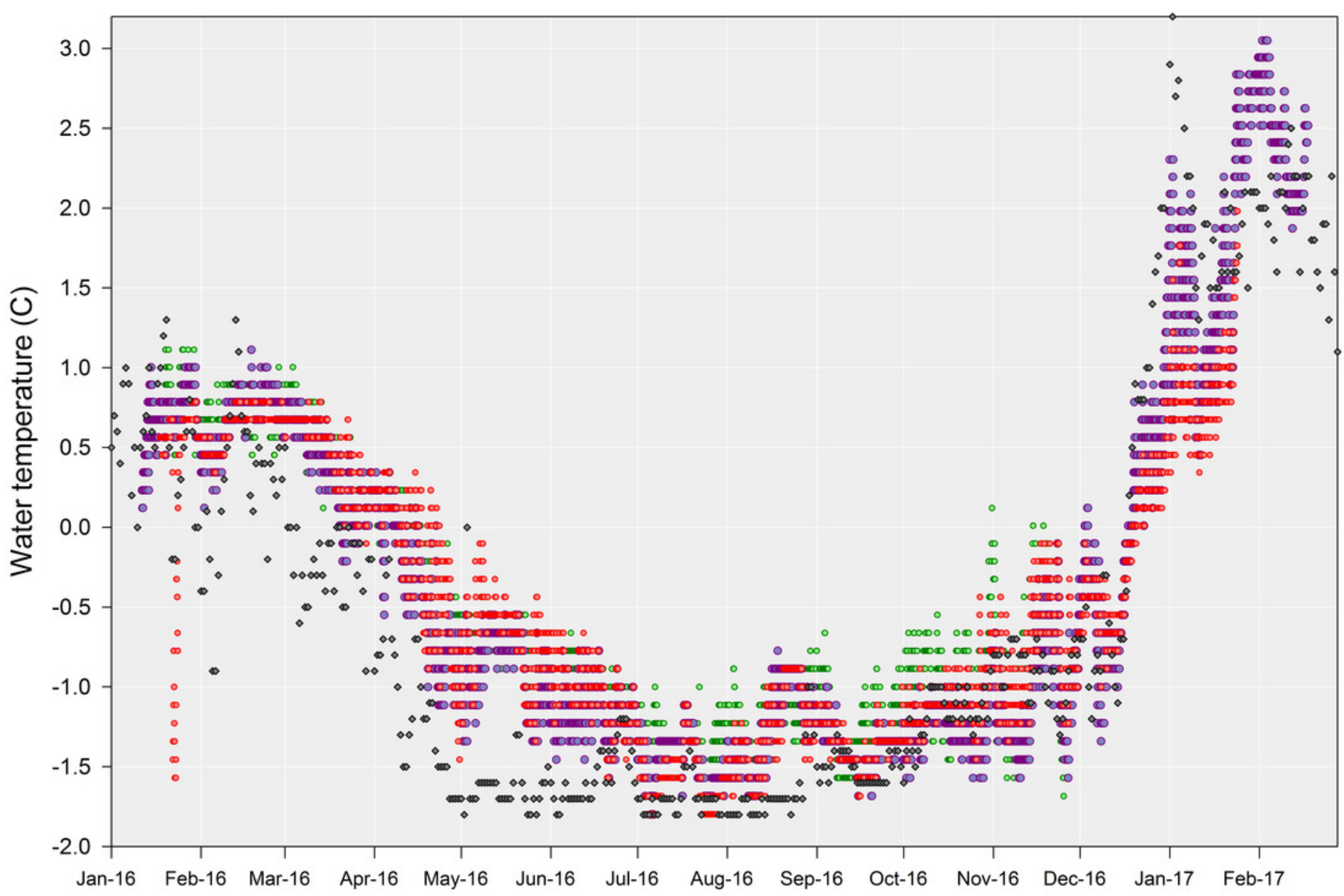




\section{Figure 5}

First derivative of seawater temperature trend from PY1 (10 m)

Fitted GAM trend $(k=58)$ showing estimate time intervals with significant rates of change in seawater temperature. Periods of significant change in the fitted trend, determined by derivative analysis, are highlighted by the thickened colored sections of the trend (red=decrease; blue=increase). Grey areas around the black line (fitted trend) indicate 95\% confidence limits, and the dots are the daily mean seawater temperature recorded at PY1 from January 11th, 2016 to February 17th, 2017 in South Bay, Doumer Island, WAP.

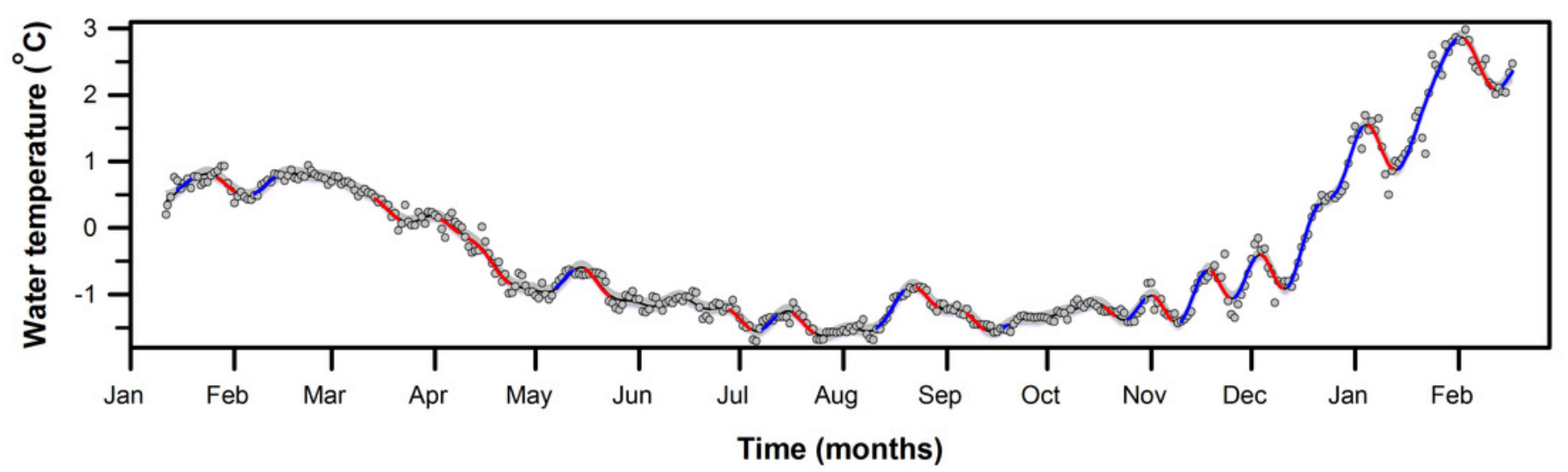




\section{Table $\mathbf{1}$ (on next page)}

Periods of significant temperature increase

Calculated warming rates $\left({ }^{\circ} \mathrm{C}\right.$ day $\left.{ }^{-1}\right)$ of periods of significant temperature increase from PY1 fitted GAM ( $k=58$, edf $=55.7, p$-value $<0.001$, Fig. 2$)$. 
Periods of significant temperature increase

Rates $\left({ }^{\circ} \mathrm{C} \mathrm{day}^{-1}\right)$
0.04
0.04
0.05
0.05
0.07
0.03
0.06
0.12
0.11
0.15
0.13
0.12

- 19 Jan 2016

7 - 13 Feb 2016

7 - 13 May 2016

8 - 12 Jul 2016

11 - 19 Aug 2016

18 - 19 Sep 2016

25 - 30 Oct 2016

0.06

10 - 17 Nov 2016

0.12

26 Nov - 2 Dec 2016

0.11

$12-21$ Dec 2016

0.13

14 - 31 Jan 2017 